\title{
AFM Force Spectroscopy Reveals the Role of Integrins and Their Activation in Cell-Biomaterial Interactions
}

\section{Harjumaki, Riina}

2020

Harjumaki , R , Zhang , X, Nugroho, R W N , Farooq, M , Lou , Y-R , Yliperttula , M , Valle-Delgado , J J \& Osterberg , M 2020 , ' AFM Force Spectroscopy Reveals the Role of Integrins and Their Activation in Cell-Biomaterial Interactions ' , ACS Applied Bio Materials , vol. 3 , no. 3 , pp. 1406-1417 . https://doi.org/10.1021/acsabm.9b01073

http://hdl.handle.net/10138/325112

https://doi.org/10.1021/acsabm.9b01073

cc_by

publishedVersion

Downloaded from Helda, University of Helsinki institutional repository.

This is an electronic reprint of the original article.

This reprint may differ from the original in pagination and typographic detail.

Please cite the original version. 


\title{
AFM Force Spectroscopy Reveals the Role of Integrins and Their Activation in Cell-Biomaterial Interactions
}

\author{
Riina Harjumäki, Xue Zhang, Robertus Wahyu N. Nugroho, Muhammad Farooq, Yan-Ru Lou, \\ Marjo Yliperttula, Juan José Valle-Delgado,* and Monika Österberg*
}

Cite This: ACS Appl. Bio Mater. 2020, 3, 1406-1417

Read Online

\section{ACCESS \\ Џlll Metrics \& More \\ Article Recommendations \\ Supporting Information}

ABSTRACT: Transmembrane protein integrins play a key role in cell adhesion. Cell-biomaterial interactions are affected by integrin expression and conformation, which are actively controlled by cells. Although integrin structure and function have been studied in detail, quantitative analyses of integrin-mediated cell-biomaterial interactions are still scarce. Here, we have used atomic force spectroscopy to study how integrin distribution and activation (via intracellular mechanisms in living cells or by divalent cations) affect the interaction of human pluripotent stem cells (WA07) and human hepatocarcinoma cells (HepG2) with promising biomaterials - human recombinant laminin-521 (LN-521) and cellulose nanofibrils (CNF). Cell adhesion to LN-521-coated probes was

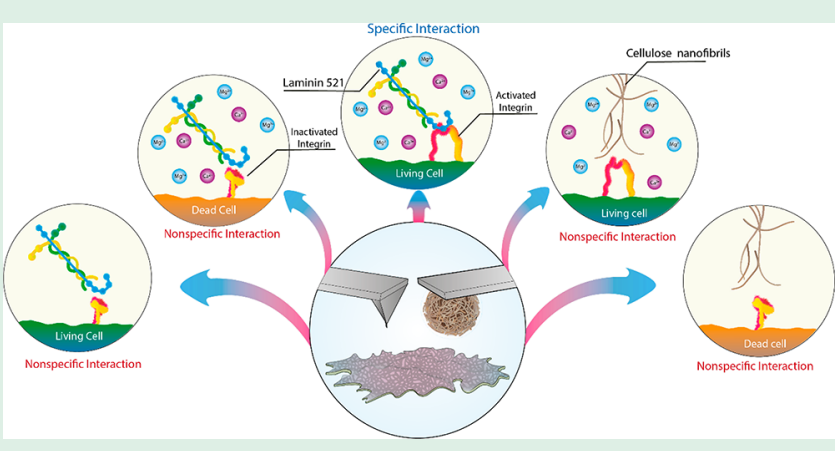
remarkably influenced by cell viability, divalent cations, and integrin density in WA07 colonies, indicating that specific bonds between LN-521 and activated integrins play a significant role in the interactions between LN-521 and HepG2 and WA07 cells. In contrast, the interactions between CNF and cells were nonspecific and not influenced by cell viability or the presence of divalent cations. These results shed light on the underlying mechanisms of cell adhesion, with direct impact on cell culture and tissue engineering applications.

KEYWORDS: integrin, human pluripotent stem cells, human hepatocarcinoma cells, cellulose nanofibrils, laminin-521, atomic force microscope, force spectroscopy, colloidal probe microscopy

\section{INTRODUCTION}

The interactions of cells with their extracellular matrix (ECM) are crucial in many biological processes, such as tissue regeneration, wound healing, embryo development, and tumor metastasis. Cell viability, proliferation, migration, and differentiation are widely affected by the interactions of the cells with the surrounding materials both in vivo and in vitro. The main mediators of cell-biomaterial interactions are cell membrane proteins called integrins. Integrins are a family of transmembrane proteins formed by two main subunits $\alpha$ and $\beta{ }^{1,2}$ In mammals, these subunits can form 24 heterodimers with specific expression in different cell types. ${ }^{3-6}$ The binding of the same ECM ligand to different integrins activates alternative signaling pathways and thus different biological responses. ${ }^{7,8}$ The interaction between cells and biomaterials can be altered when the integrin cassette of cells changes, for example, in stem cell differentiation or cancer propagation. ${ }^{9}$

Integrins are components of a complex assembly of proteins called focal adhesions, with over 150 different associated molecules. ${ }^{9,10}$ They can be in an inactivated or activated conformation. ${ }^{5,11}$ Due to their dynamic nature, they can transmit bidirectional signals through the cell membrane. ${ }^{5,12,13}$ Inside-out signals from cell membrane receptors increase the ligand binding affinity of integrins. On the other hand, the binding of ligands to integrins triggers the creation of focal adhesion complexes and the activation of downstream signal pathways. The binding of integrins to their ligands is influenced by divalent cations, with $\mathrm{Mn}^{2+}$ and $\mathrm{Mg}^{2+}$ generally promoting the binding and $\mathrm{Ca}^{2+}$ preventing it. ${ }^{5,14-16}$ Nevertheless, this cation effect is also concentration dependent. ${ }^{17} \mathrm{~A}$ micromolar $\mathrm{Ca}^{2+}$ concentration is known to be required for cell-biomaterial binding, but this binding can be inhibited by higher $\mathrm{Ca}^{2+}$ concentrations in the millimolar range, in the presence of $\mathrm{Mg}^{2+}$. However, quantitative analyses of the effect of divalent cations on cell-biomaterial interactions are still very scarce. Depending on the biomaterial nature and integrin conformation, specific or nonspecific interactions with activated or inactivated integrins can take place, all of them affecting the behavior of cells. ${ }^{18}$

Received: November 22, 2019

Accepted: February 12, 2020

Published: February 12, 2020 
The atomic force microscope (AFM) is a suitable instrument to quantify cell-biomaterial interactions in physiological conditions with high sensitivity (in the order of picoNewtons, $\mathrm{pN}) .{ }^{19,20}$ Other techniques, like magnetic or optical tweezers, can measure interactions with higher sensitivity (below $1 \mathrm{pN}$ ), but the maximum forces that they can detect are usually below $1 \mathrm{nN}$. A broader range of forces can be measured by AFM, from $10 \mathrm{pN}$ to $100 \mathrm{nN}$, which makes AFM a very convenient instrument to study cell adhesion. AFM-based force spectroscopy techniques have been proven to be suitable to quantify cell-biomaterial interactions in detail. ${ }^{19,21-25}$ In particular, the AFM has been used to measure the binding forces of integrins to some ligands, which were usually in the range of several tens of $\mathrm{pN}^{21,28-30}$ Nevertheless, these studies provide information on only some particular cell lines and ligands. In some cases, the use of isolated adhesion peptides as ligands may not represent the real situation, as the binding of integrin to the whole proteins may differ from the binding to the isolated peptides. ${ }^{26}$ The specificity of integrin-ligand interaction has also been studied by blocking the integrins with antibodies. ${ }^{25,29}$ Although this is a very efficient approach to block integrinspecific interactions, it is still uncertain whether the introduced antibodies could contribute with some nonspecific interactions to the total adhesion between cells and ligands. Furthermore, in cells expressing different types of receptors for the same ligand, it is not feasible to efficiently block all specific bonds using antibodies. Hence, alternative approaches have been used in this work to elucidate the contribution of specific integrin-ligand bonds to the total interaction forces between cells and biomaterials in as natural conditions as possible.

The cells chosen for this study were human pluripotent stem cell (hPSCs) line WA07 and human hepatocarcinoma cell (HCC) line HepG2. hPSCs have a potential to differentiate into any cell type of the human body and are thus a promising cell source for various in vitro cell culture applications such as drug toxicity testing and clinical applications. Due to their sensitivity, they have not been extensively studied with AFM, and their interactions with biomaterials used in tissue engineering are largely unknown. ${ }^{24}$ Närvä et al. recently showed that integrins are preferentially expressed at the peripheral areas of hPSC colonies. ${ }^{31}$ Thus, the unique localization of integrins in hPSCs offered us an excellent opportunity to quantify the effect of integrins on cellbiomaterial interactions in the cells' natural stage, without the need for blocking the integrins. On the other hand, HepG2 cells, a model for carcinoma cell type and widely used for in vitro drug toxicity testing, were used in this work for comparison. AFM force spectroscopy was applied to measure the interaction of WA07 and HepG2 cells with novel biomaterials used in cell cultures: human recombinant laminin-521 (LN-521) and wood-derived, chemically unmodified cellulose nanofibrils (CNF). It has previously been shown that in two-dimensional (2D) cell cultures hPSCs can be maintained on the laminin-521 matrix, ${ }^{32}$ and this material can also be used to guide stem cell differentiation to hepatic cells. ${ }^{33}$ On the other hand, CNF can facilitate the formation of hepatic (HepaRG and HepG2) and stem cell spheroids in threedimensional (3D) cell cultures. ${ }^{34-36}$ A deeper insight into the mechanisms of interaction of these materials with cells can foster their potential utilization in tissue engineering and biomedical applications.

Single-cell force spectroscopy (SCFS), where a cell is attached to the AFM cantilever, has been commonly used in the literature to study the adhesion of several cell types to different materials by AFM. ${ }^{19,20,37,38}$ However, SCFS is not a suitable method to investigate hPSCs because these cells die quickly when they are isolated from the cell colonies. Instead, in this work we have applied colloidal probe microscopy (CPM), where colloidal probes attached to AFM cantilevers are used as force sensors. ${ }^{39}$ CPM has been widely used in material research, but the method has also been applied to measure the adhesion between cells and colloidal probes coated with different biomaterials. ${ }^{40-42}$

Both cell viability and the presence of divalent cations can affect the activation of integrins and, consequently, the cellbiomaterial interactions. To date, the role of active control of integrin activation in the overall cell-biomaterial interactions is still unclear. Although it is known that cell viability has a high impact on cell-biomaterial interactions, no quantitative analysis of its impact has been accomplished in previous cellbiomaterial interaction studies. Taubenberger et al. studied the adhesion of collagen I to Chinese hamster ovary cells expressing or lacking $\alpha_{2} \beta_{1}$ integrins, revealing the role of integrin clustering in mediating cell-biomaterial interaction. ${ }^{21}$ Nevertheless, the effect of different inside-out activation signals could not be detected with their approach. Thus, force experiments with both dead and living cells in the absence and presence of $\mathrm{Ca}^{2+}$ and $\mathrm{Mg}^{2+}$ cations - at similar concentrations as in cell culture media- were carried out in this work to determine the contribution of integrin-mediated interactions to the adhesion of WA07 and HepG2 cells to LN-521 and CNF substrates. The results of the quantitative analysis of the cellbiomaterial interactions presented herein can be used to understand and tailor cell adhesion in different cell culture, tissue engineering, and regenerative medicine applications.

\section{EXPERIMENTAL SECTION}

Preparation of Biomaterial Solutions and Dispersions. All biomaterial solutions and dispersions were prepared as described in previously published protocols. $^{24,43}$ The protocols for laminin solution were provided by a supplier and CNF dispersion by ValleDelgado et al. ${ }^{44}$ Briefly, the human recombinant laminin (LN521-02, $0.10 \mathrm{mg} / \mathrm{mL}$, Biolamina) and cellulose nanofibrils in a hydrogel form (Growdex, UPM-Kymmene) were diluted from the stock concentrations with Dulbecco's phosphate-buffered saline with calcium and magnesium $(1 \times$ DPBS+, 14040-133, GibcoTM $)$ and deionized water, respectively. The diluted CNF dispersion with $0.875 \%$ dry matter content was ultrasonicated for $1 \mathrm{~min}$ at $25 \%$ amplitude using a Branson sonifier S-450D tip (Branson Corp.). After that, the CNF dispersion was centrifuged at $8000 \mathrm{~g}$ for $30 \mathrm{~min}$ using an Eppendorf 5804R centrifuge (Eppendorf $A G$ ), and the supernatant with the thinnest CNF fibrils was stored at $+4{ }^{\circ} \mathrm{C}$. LN-521 $(10 \mu \mathrm{g} / \mathrm{mL})$ was stored at $-20{ }^{\circ} \mathrm{C}$, thawed, and kept at $+4{ }^{\circ} \mathrm{C}$ for a maximum of 2 weeks prior to use.

Preparation of Biomaterial-Coated Cantilevers. Different AFM probes were used for the force measurements: CSC38/No $\mathrm{Al}$ $(0.03-0.15 \mathrm{~N} / \mathrm{m}$ spring constant), NSC $36 / \mathrm{Cr}-\mathrm{Au}(0.7-1.3 \mathrm{~N} / \mathrm{m}$ spring constant), and $\mathrm{NSC} 35 / \mathrm{Cr}-\mathrm{Au}(8.8 \mathrm{~N} / \mathrm{m}$ spring constant) tipless cantilevers (MikroMasch, Wetzlar, Germany) and PFQNMLC-A probes with $65 \mathrm{~nm}$ tip radius and $0.04-0.06 \mathrm{~N} / \mathrm{m}$ spring constant (Bruker AFM Probes, Camarillo, CA). Colloidal probes were prepared by attaching glass beads with diameters between 16 and 40 $\mu \mathrm{m}$ (Polysciences, Inc., Table S1) at the free end of the tipless cantilevers. A motorized PatchStar micromanipulator (Scientifica, Uckfield, UK) was used for precise positioning of the beads, which were glued on the cantilevers using an optical adhesive (Norland Products, Inc., Cranbury, NJ) that was cured under UV light (365 nm wavelength) for $15 \mathrm{~min}$. The diameter of the colloidal probes was 

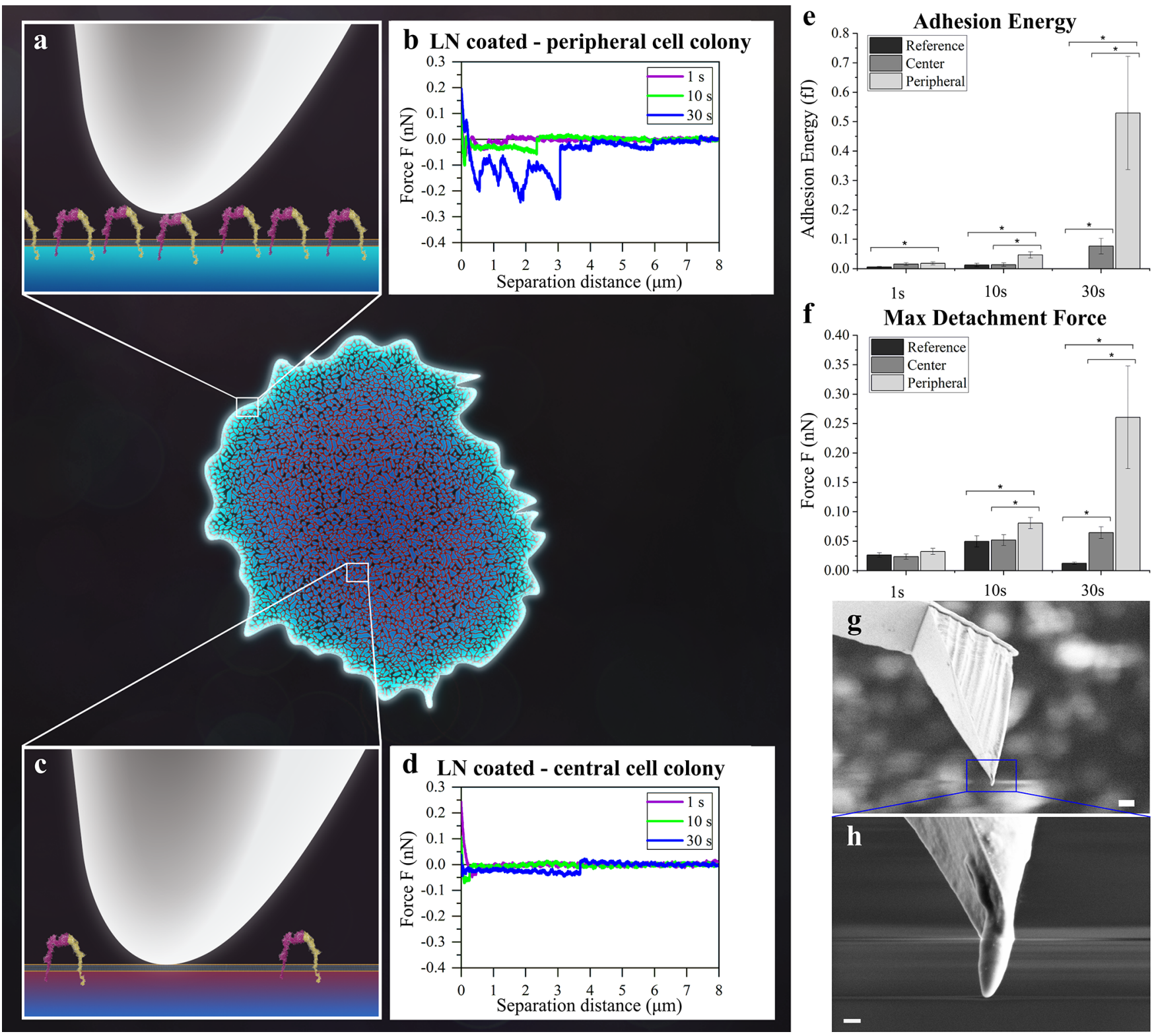

Figure 1. Effect of integrin location on the binding of LN-521 to WA07 cell colonies. The assumed integrin density, based on previous results by Närvä et al., ${ }^{31}$ is represented as a gradient in blue (the lighter the blue, the higher the integrin density) in the central schematic illustration of a WA07 cell colony of a few $\mathrm{mm}^{2}$ area. Schematic illustrations and representative retraction force curves for the contact of a LN-521-coated tip with integrin-enriched, peripheral areas $(\mathrm{a}, \mathrm{b})$ or integrin-deprived, central areas $(\mathrm{c}, \mathrm{d})$ of WA07 cell colonies. Note that the boxes are only rough illustrations and do not depict exact positions of force measurements. The retraction force curves were obtained after different cell-probe contact times (1, 10, and $30 \mathrm{~s}$ ). Mean values of adhesion energy (e) and maximum (max) detachment force (f) between LN-521-coated tips and WA07 cells at central or peripheral areas of cell colonies after different cell-tip contact times. Reference values correspond to adhesion experiments carried out with bare tips. The amount of force curves per sample is presented in the Supporting Information (Table S2). Error bars are standard errors of mean, and significant differences $(p \leq 0.05)$ are marked with *. The experiments were carried out in PBS+ using PFQNM-LC-A probes (tip of $65 \mathrm{~nm}$ contact radius). SEM images of the probes are shown in $(\mathrm{g}, \mathrm{h})$; scale bars $2 \mu \mathrm{m}(\mathrm{g})$ and $0.2 \mu \mathrm{m}$ (h). The force curves, adhesion energies, and maximum detachment forces were not normalized by the probe radius $R$.

measured using a Leica DM750 microscope and LAS EZ software (Leica Microsystems, Wetzlar, Germany).

Tipless cantilevers with attached beads were coated with CNF or LN-521 by adsorption, as previously described. ${ }^{24,43}$ Briefly, colloidal probes previously precoated with polyethylenimine (Sigma-Aldrich) were immersed in drops of CNF dispersion for $10 \mathrm{~min}$, rinsed with Milli-Q water, and dried with nitrogen. LN-521-coated colloidal probes were obtained by placing the colloidal probes in LN-521 solution drops for ca. $2 \mathrm{~h}$. After that, the probes were rinsed with PBS + and directly utilized in the force experiments without drying. These adsorption procedures produced colloidal probes completely coated with layers of CNF and LN-521 that were stable during the force experiments as shown previously. ${ }^{24}$ Probes with $65 \mathrm{~nm}$ tip radius were used as such (reference) or coated with LN-521 in a similar way as the colloidal probes.

Cell Culture. For maintenance, human cell lines HCC HepG2 (HB-8065, ATCC) and hPSC WA07 (WiCell) were cultured in wellestablished cell culture conditions at $37{ }^{\circ} \mathrm{C}$ in a humid atmosphere with $5 \% \mathrm{CO}_{2}$. HepG2 cells were grown in a $\mathrm{T} 75$ plastic bottle in DMEM medium with high glucose and pyruvate content (41966-029, GibcoTM) supplemented with $10 \%$ fetal bovine serum (10270-106, GibcoTM) and WA07 on 6-well plates coated with Matrigel (Matrigel 
basement membrane matrix growth factor reduced, 356230, BD Biosciences, $0.5 \mathrm{mg}$ per one 6-well plate) in mTeSR1 medium (05850, STEMCELL Technologies) that was renewed every day. HepG2 cells were passaged twice a week at a ratio of $1: 5$ by using TrypLETM Express (GibcoTM, 12604-021), and WA07 cells were split with Versene 1:5000 (Invitrogen, 15040-033) at a ratio of 1:4$1: 6$, when cell confluency reached $70 \%$. Differentiated WA07 cells were manually removed before the splitting. Cell growth and morphology were monitored using a Leica DM IL LED phase contrast microscope and LAS EZ software (Leica Microsystems).

For AFM experiments, the HepG2 cells were cultured on uncoated plastic coverslips (83.1840.002, Sarstedt), whereas the WA07 cells were cultured on Matrigel-coated, plastic coverslips. In both cases, cells were kept in 12-well plates for at least 2 days before the force measurements to allow good cell attachment and confluency above $40 \%$. For AFM studies with dead cells, the cells were fixed with $4 \%$ paraformaldehyde (PFA) at RT for 10 min, washed three times with 1 $\times$ PBS, and kept at $+4{ }^{\circ} \mathrm{C}$ in $1 \times$ PBS for a maximum of 2 weeks. Before AFM experiments, living cells were washed twice with either 1 $\times$ PBS - or $1 \times \mathrm{PBS}+$, depending on the medium used for the measurements.

Force Measurements. A MultiMode 8 AFM with a NanoScope V controller (Bruker, Santa Barbara, CA) was used for all AFM experiments. A closed-loop PicoForce scanner (Bruker) was employed for the force measurement. The experiments with living cells were carried out at $37{ }^{\circ} \mathrm{C}$ (Thermal Applications Controller, Bruker), whereas the measurements with dead cells were accomplished at RT. Before the force measurements and before attachment of colloidal spheres, the spring constants of the probes were determined by analyzing their thermal fluctuation spectra and by applying Sader's equation, ${ }^{45}$ whereas the spring constants of the PFQNM-LC-A probes with $65 \mathrm{~nm}$ tip radius were obtained by the thermal noise method. ${ }^{46}$ The deflection sensitivity was determined on a hard, freshly cleaved mica surface to avoid errors due to soft substrates. ${ }^{43}$

After mounting the cells and the probes in the AFM liquid cell, the system was allowed to equilibrate for $10 \mathrm{~min}$ in the buffer solution (PBS+ or PBS-) before the force measurements. The interaction forces between biomaterials and cells were recorded at a $2 \mu \mathrm{m} / \mathrm{s}$ rate with at least $20 \mathrm{~s}$ lag for living cells and $1 \mathrm{~s}$ lag for dead cells between two successive approach-retraction cycles. The maximum applied force was in the range $0.25-0.40 \mathrm{nN}$ for the experiments with the PFQNM-LC-A probes. The maximum applied force, normalized by the probe radius, was $0.15-0.8 \mathrm{mN} / \mathrm{m}$ (typically around $0.6 \mathrm{mN} / \mathrm{m}$ ) for the experiments with the colloidal probes. In order to study the effect of the contact time on the cell-material adhesion, cells and biomaterials were kept in contact for 1, 10, and $30 \mathrm{~s}$ before retracting them. Within an experiment for a particular cell-biomaterial system, the maximum applied force was the same for all the contact times. For each cell-material system, several force curves were recorded in different locations of the same or different cell plates, using between 1 and 3 probes in the same or different days to check the reproducibility of the measurements. The cell viability and probe location during force experiments were monitored with a digital camera (uEye UI148XLE-C camera) connected to the AFM. Typically, cells detached gradually before dying after $2 \mathrm{~h}$ of experiments, which was clearly observed with the digital camera. The experiments were stopped immediately if any sign of detachment was noted. Consequently, the measurement time was usually kept under 1.5 or $2 \mathrm{~h}$ for WA07 and HepG2 cells, respectively.

Since colloidal probes with different radii offered different contact areas to cells - and that can affect the intensity of the measured forces because the amount of probed receptors differs- the force curves obtained with the colloidal probes were normalized by the radius of the attached bead, which is a common practice when using the colloidal probe microscopy. ${ }^{47}$ The force normalization was performed by applying the equation normalized force $=F / R$, where $F$ is the measured unnormalized force and $R$ is the radius of the colloidal probe. It should be noted that force normalization by $F / 2 \pi R$ is also often done because, according to Derjaguin's approximation, that normalization is directly the interaction energy per unit of area between two flat surfaces; ${ }^{48}$ however, normalization by $F / R$ is more usual in the literature. ${ }^{47}$ Cell-biomaterial adhesion energies were obtained by integrating the areas confined between the retraction force curves (force values below 0) and the zero baselines (Figure S1). Maximum detachment forces were identified as the maximum adhesion forces (in absolute value) observed in the retraction force curves (Figure S1).

Scanning Electron Microscopy. The cell surface morphology was visualized with a scanning electron microscope (SEM; FEI Quanta series). First, the cell surface was protected with silica as described earlier. ${ }^{49,50}$ Briefly, the PFA-fixated cells were incubated in a tetraethyl orthosilicate solution for 24-72 h, washed with water and methanol solutions, and dried in air. Samples were deposited on borosilicate cover glasses or silicon substrates and sputter-coated with $\mathrm{Au} / \mathrm{Pd}$.

After their use in force experiments, AFM probes were visualized by a field-emission scanning electron microscope (FESEM; Zeiss Sigma VP). AFM cantilevers were mounted on double-sided carbon tape fixed on the FESEM metal stubs. Micrographs were recorded at an accelerating voltage of 1 or $2.5 \mathrm{kV}$ using a secondary electron detector at a working distance of 3-6 mm. Fiji ImageJ software (Research Services Branch, NIH, Bethesda) was used for the image analysis.

Statistical Analysis. Adhesion energy and maximum detachment forces were calculated with OriginPro software (OriginLab Corporation). In general, between 20 and 172 force curves were recorded per system at each contact time on at least two different locations (Tables S2, S3, and S4). Less than 20 force curves for each contact time were analyzed only in some systems and controls showing low adhesion and low variability between measurements. The calculated data were expressed as mean values \pm standard errors of the mean. A Welch's $t$ test was applied to estimate the statistical difference between the mean values of two independent groups of data. The data were considered significantly different when $p \leq 0.05$.

\section{RESULTS AND DISCUSSION}

Effect of the Location of Activated Integrins on the Adhesion between WA07 Cells and LN-521. The ECMprotein $\mathrm{LN}-521$ is a known ligand of integrins in native WA07 cells. Special AFM tips (PFQNM-LC-A) of $65 \mathrm{~nm}$ contact radius coated with $\mathrm{LN}-521$ were used to measure the interaction forces with cells at different locations of WA07 colonies (representative retraction force curves are shown in Figure 1, whereas representative approach force curves are presented in Supporting Information, Figure S2). A significant difference in LN-521-WA07 adhesion was observed between the peripheral and central areas of the WA07 colonies after contact times $\geq 10 \mathrm{~s}$, especially remarkable after $30 \mathrm{~s}$ contact time (Figures $1 \mathrm{~b}, \mathrm{~d}-\mathrm{f}$ and Table S2). After $30 \mathrm{~s}$ contact time, the adhesion energy and the maximum detachment force of LN-521 to integrin-enriched, peripheral areas were $0.53 \pm 0.19$ fJ and $0.26 \pm 0.09 \mathrm{nN}$, respectively, considerably stronger than in the central areas $(0.077 \pm 0.026 \mathrm{fJ}$ and $0.065 \pm 0.010 \mathrm{nN}$, respectively). This type of contact-time-dependent adhesion has been shown to be typical for integrins. ${ }^{21}$ Furthermore, the retraction force curves between laminin-coated AFM tips and peripheral areas of WA07 colonies showed a sawtooth pattern after contact times $\geq 10 \mathrm{~s}$ (especially evident after $30 \mathrm{~s}$ contact time, Figure $1 b$ ), which was absent in the force curves obtained in the central areas of the colonies (Figure 1d). The sawtooth pattern is characteristic of the unbinding events of cell membrane proteins anchored to the cytoskeleton (like activated integrins). ${ }^{51}$ In contrast, some retraction force curves at the central areas of WA07 colonies showed step-like patterns, commonly associated with tether formation, that is, 

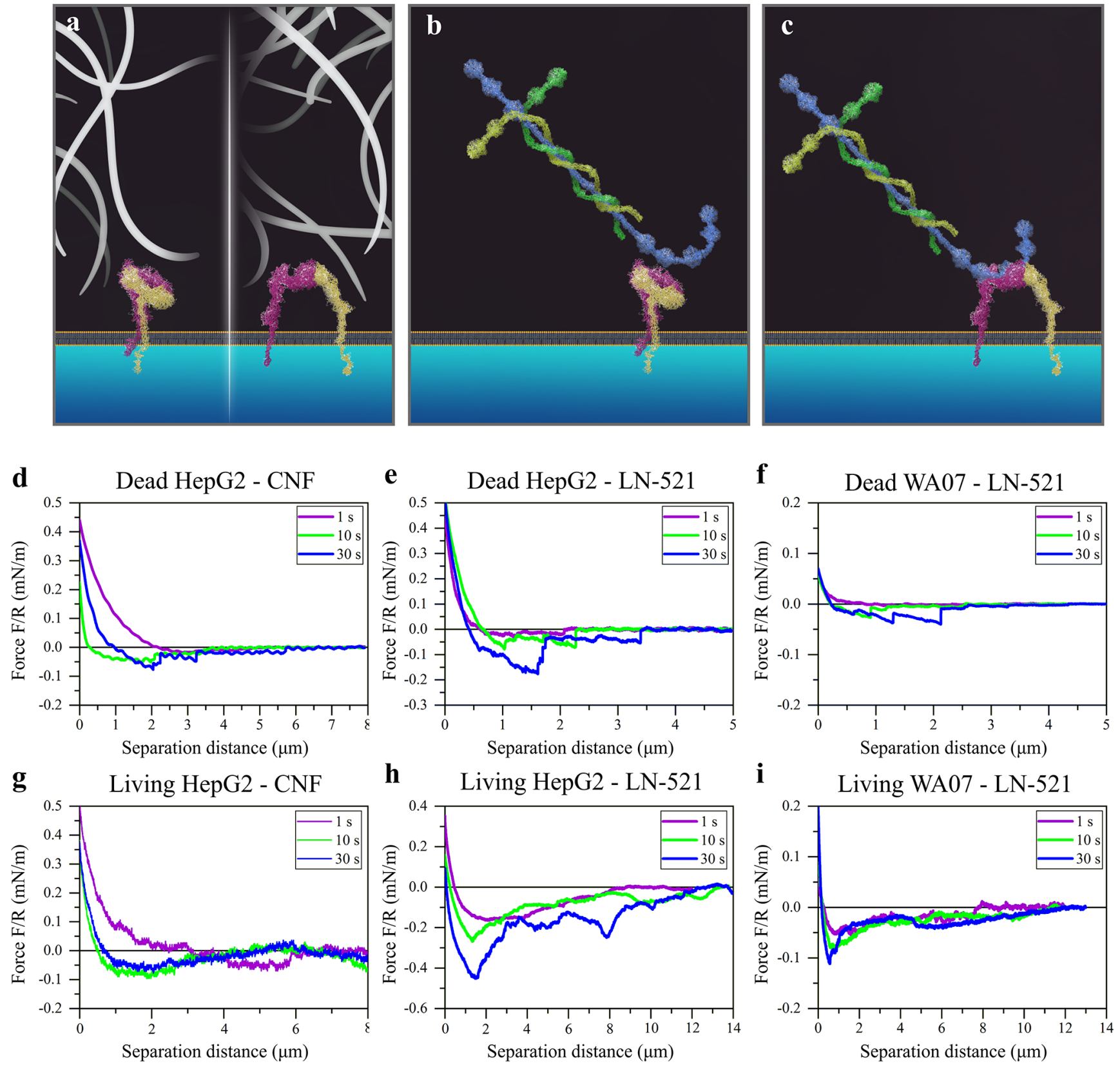

j

$\mathbf{k}$

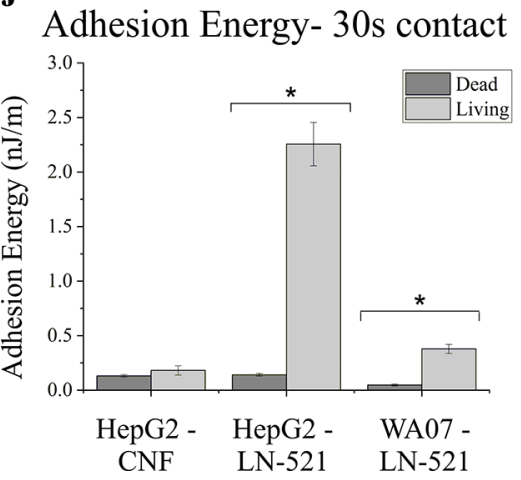

Max Detachment Force - 30s contact

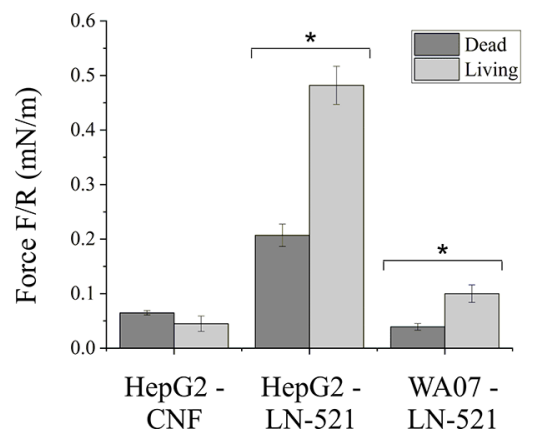

LN-521-Coated Colloidal Probe

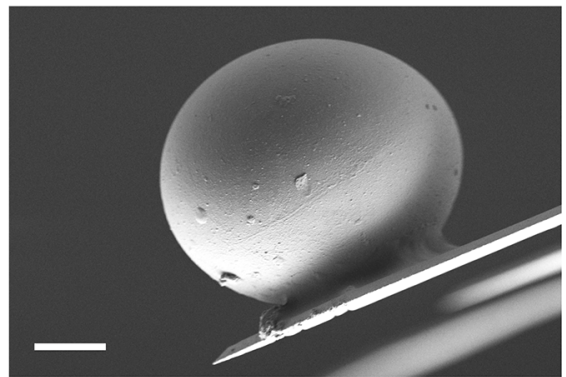

Figure 2. Effect of cell viability on cell-biomaterial interactions. Schematic illustrations of the contact between CNF and integrin in inactive and active conformation (a) and the contact between LN-521 and integrin in inactive (b) and active (c) conformation. Representative retraction force curves between LN-521- or CNF-coated colloidal probes and living or dead HepG2 and WA07 cells measured in PBS+ after different cell-probe contact times $(\mathrm{d}-\mathrm{i})$. Mean values of adhesion energy and maximum $(\max )$ detachment force for dead and living cells after $30 \mathrm{~s}$ contact time are 
Figure 2. continued

compared in $(j)$ and $(k)$, respectively. Error bars are standard errors of mean, and significant differences $(\leq 0.05)$ are marked with $*$. The force curves, adhesion energies, and maximum detachment forces were normalized by the probe radius $R$. The probe radii, the adhesion energies, the maximum detachment forces, and the number of force curves per sample are presented in the Supporting Information (Tables S1, S3, and S4). A SEM image of a LN-521-coated colloidal probe is shown in (1); scale bar $10 \mu \mathrm{m}$. SEM images of a CNF-coated colloidal probe are shown in the Supporting Information (Figure S3).

unbinding of cell membrane spots not attached to the cytoskeleton. Using immunofluorescence microscopy, Närvä et al. have shown that there is a higher density of integrins at the peripheral areas of hPSC colonies as compared to the

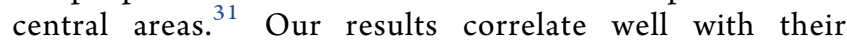
observations and suggest that the adhesion of LN-521 to peripheral areas of WA07 colonies would be dominated by specific integrin-LN-521 bonds. The fact that the sawtooth patterns and high adhesion energies were particularly observed after $30 \mathrm{~s}$ contact time suggests that integrin activation and binding to $\mathrm{LN}-521$ could be favored by cell rearrangement and deformation to adapt the cell to the tip geometry during contact. This rearrangement may increase the tip-cell contact area, exposing more integrin molecules to $\mathrm{LN}-521$ as the contact time increases.

Control experiments with bare (uncoated) tips showed similar low adhesion as LN-521-coated tips to central areas of WA07 colonies (Figures 1e,f, and S2 and Table S2), indicating that the interaction between LN-521 and WA07 at the central areas of the cell colonies is mainly nonspecific, that is, not mediated by integrins. In line with this conclusion, it must be noted that the maximum detachment forces between LN-521coated tips and central areas of WA07 colonies were very often below 50-100 $\mathrm{pN}$, which is the typical range for a single integrin-ligand bond in living cells. ${ }^{30}$ In contrast, LN-521coated tips adhered more strongly to peripheral areas of WA07 cell colonies, with maximum detachment forces similar to $1-5$ integrin-ligand bonds.

It should be noted that the stability of the LN-521 coatings on PFQNM-LC-A tips was confirmed from the reproducibility of the force measurements. The strong adhesion between a LN-521-coated tip and a peripheral area of a WA07 cell colony after $30 \mathrm{~s}$ contact time was indeed remarkably reduced after moving the tip toward a central area of the colony. However, a strong adhesion was detected again as soon as the tip was moved to probe another peripheral area of the cell colony, showing that LN-521 had not detached from the tip during the measurements. A weak adhesion was observed once more when the same tip was finally used to probe another spot in the middle of the WA07 colony. The reproducibility of the measurements confirmed the integrity of the LN-521 coating and that the observed reduction in adhesion was not due to degradation of the LN-521 coating but to the lower expression of integrins in the central areas of WA07 colonies.

In summary, these results agree with the presence of activated integrins at the edge areas of the WA07 colonies as observed by Närvä et al. ${ }^{31}$ and offer a unique quantitative comparison between specific (integrin-mediated) and nonspecific cell-LN-521 interactions within WA07 colonies in natural conditions.

The possibility that integrins could be mainly sequestered at the basal side of the cells - in the focal adhesions between the cells and the underlying substrate - is a relevant point for this work because the apical (and not the basal) side of the cells was probed in our approach. The results presented in this and the following sections indicate that integrins are also present in the apical side of WA07 and HepG2 cells, in line with previous observations on Madin-Darby canine kidney cells by Schoenenberger et al. ${ }^{52}$

Effect of Cell Viability on Cell-Biomaterial Interactions. Cells can actively control integrin conformation. Consequently, integrin activation and integrin-mediated cellbiomaterial interactions depend on cell viability. The effect of integrin conformation on cell-biomaterial interactions was evaluated in this work by comparing the interaction forces of living and dead cells with LN-521 and CNF biomaterials (Figure 2). This approach was used instead of blocking the integrins with antibodies, which is not a suitable method to prevent efficiently all specific bonds in cells - like the ones used in this study - expressing different types of lamininbinding integrins. Colloidal probes with radii between 8 and 20 $\mu \mathrm{m}$, coated with LN-521 or CNF, were used in this study (Figures $2 \mathrm{l}$ and S3). These colloidal probes offer a larger surface for long cellulose nanofibrils, which have certain restrictions in flexibility, to adsorb better than on small PFQNM-LC-A tips. These large colloidal probes also give the possibility to potentially measure the adhesion of biomaterials to whole cells. The stability of the CNF and LN-521 coatings on the colloidal probes was confirmed from the reproducibility of the force measurements and the comparison with control experiments using probes without biomaterial coatings, as shown in our previous work. $^{24}$ Paraformaldehyde (PFA) fixation was used to obtain dead cells. While this treatment may mask cytoplasmic tails of integrins, it does not destroy integrin binding sites on the cell membrane. ${ }^{53}$ The formation of focal adhesions between cells and materials proceeds in a sequential manner where the initial binding of ligands to cell receptors (for instance, integrins) is usually followed by receptor clustering. Since we wanted to focus our study on the integrin-ligand interaction before integrin clustering, our force measurements were carried out at contact times below $60 \mathrm{~s}$, which has been suggested to be the time for integrin clustering onset. $^{21}$

Wood-derived, chemically unmodified CNF is a novel cell culture material that has gained a lot of interest because it can be used to culture various cell types in three-dimensional (3D) environment. $\mathrm{CNF}$ is a sterile, xeno-free, nontoxic material that is able to form networks resembling ECM topography, and its stiffness can easily be tuned by changing the CNF concentration. ${ }^{34}$ The cells cultured in CNF hydrogels form in vivo-like cell structures. ${ }^{35,36,49}$ In order to further exploit $\mathrm{CNF}$ in tissue engineering or regenerative medicine applications, a detailed understanding of the CNF-cell interactions is needed. The retraction force curves between CNF-coated colloidal probes and dead or living HepG2 cells (Figures 2d,g) were surprisingly similar, with low values of adhesion energy and detachment forces that were not statistically different (Figures $2 \mathrm{j}, \mathrm{k}$ ). Furthermore, a comparable low adhesion was observed between bare glass colloidal probes and living HepG2 cells - an interaction that is supposed to be 
Living Cells
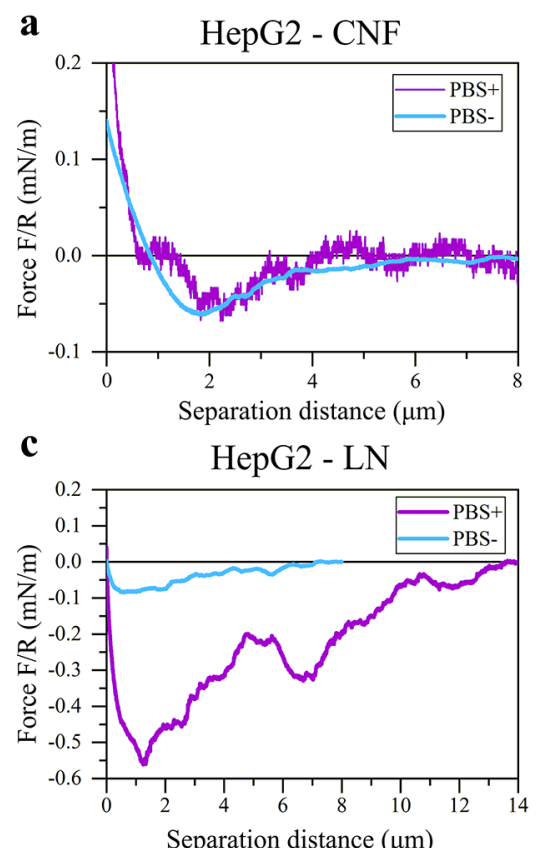

\section{Dead Cells}
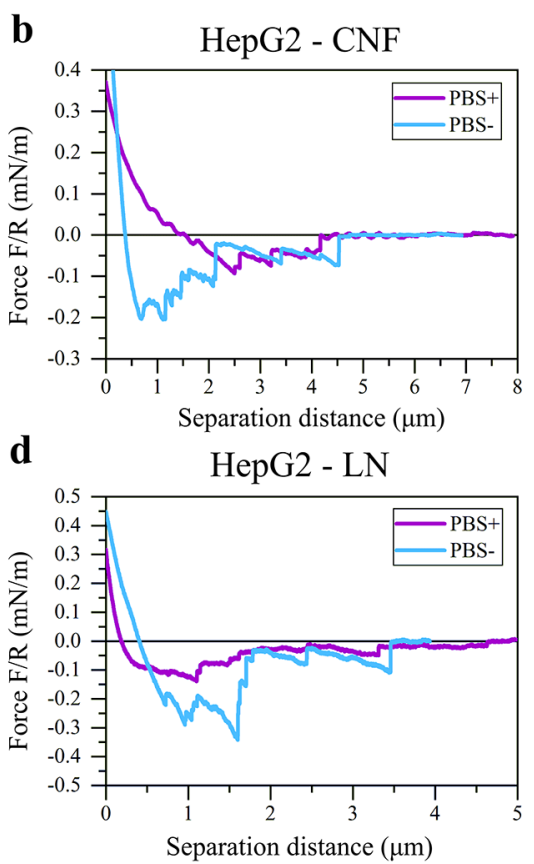

e

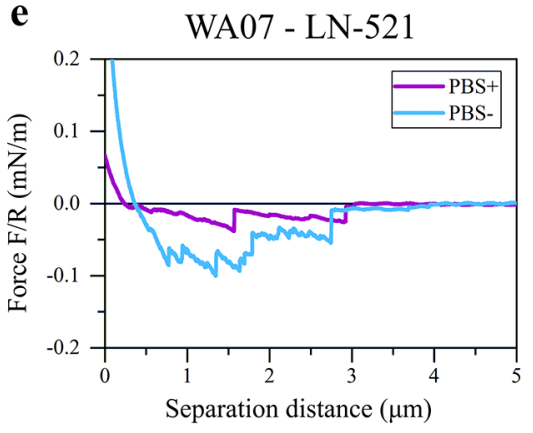

f

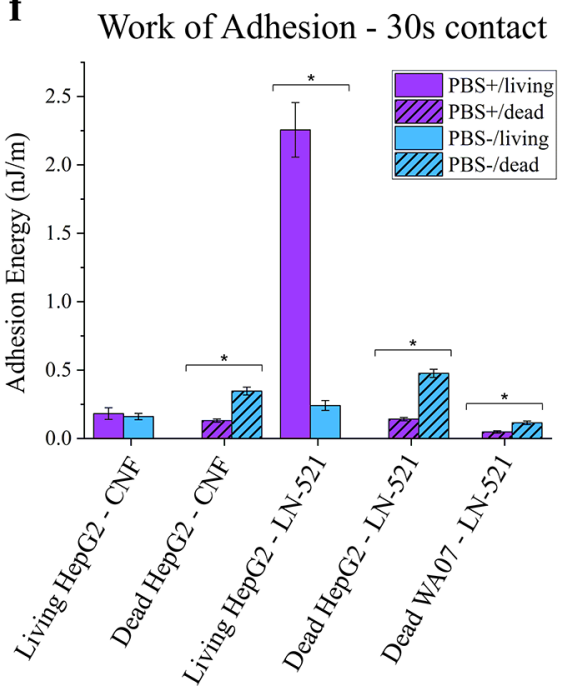

g

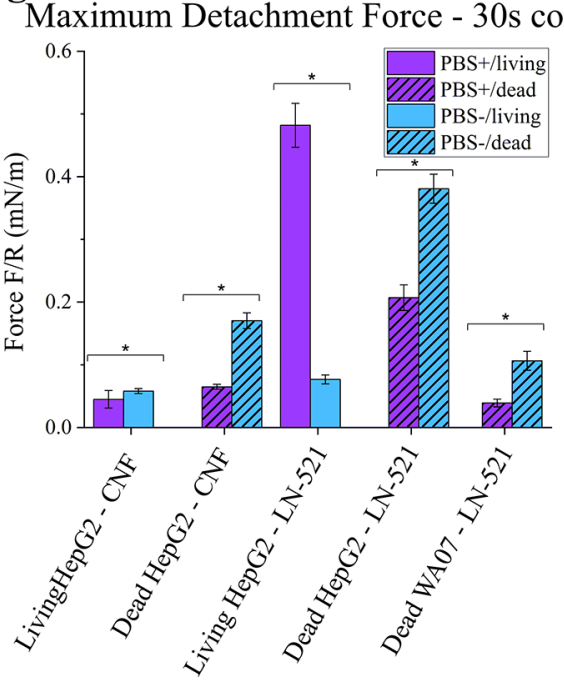

Figure 3. Effect of divalent cations $\mathrm{Mg}^{2+}$ and $\mathrm{Ca}^{2+}$ and cell viability on cell-biomaterial interactions. Representative retraction force curves between LN-521- or CNF-coated colloidal probes and HepG2 (living or dead) cells and WA07 (dead) cells measured in PBS+ and PBS- buffers after different cell-probe contact times $(\mathrm{a}-\mathrm{e})$. Mean values of adhesion energy and maximum detachment force after $30 \mathrm{~s}$ contact time are compared in (f) and $(\mathrm{g})$, respectively. Error bars are standard errors of mean, and significant differences $(p \leq 0.05)$ are marked with *. The force curves, adhesion energies, and maximum detachment forces were normalized by the probe radius $R$. The probe radii, the adhesion energies, the maximum detachment forces, and the number of force curves per sample are presented in the Supporting Information (Tables S1, S3, and S4). The higher noise level of the purple line in (a) is due to the use of a stiffer probe.

nonspecific- in control experiments reported previously. ${ }^{24}$ This experimental evidence indicates that the interaction between CNF and HepG2 seems to be nonspecific, at least not mediated by integrins.

On the contrary, the interactions of cells with LN-521 were remarkably affected by cell viability. The retraction force curves presented in Figures 2e,h for HepG2 and in Figure 2f,i for WA07 show a clear difference in the range and the magnitude of the adhesive forces between LN-521 and living or dead cells. In principle, it could be argued that the effect of cell viability on the adhesion of LN-521 to cells could be associated with the different elasticity of dead and living cells, which would result in different contact areas with the colloidal probes. The observed increase in adhesion between LN-521coated colloidal probes and living cells with the contact time would be in line with an increase in the contact area due to cell viscoelastic adaptation to the probe geometry along the time. A smaller cell-probe contact area would be expected in the case of dead cells due to the stiffer nature of the fixed cells, resulting in lower adhesion. However, our results could not be explained by only considering differences in the contact area. The adhesion of CNF-coated colloidal probes to living cells was remarkably lower than the adhesion of LN-521-coated colloidal probes and not much dependent on the contact time. LN-521 is a ligand for $\alpha_{6}$ and $\beta_{1}$ integrins expressed on HepG2 and WA07 cells, and therefore the interaction of LN521 with activated integrins could explain - together with differences in the contact area- the stronger adhesion observed with living cells (Figures $2 \mathrm{j}, \mathrm{k}$ ). Thus, the increase in contact area due to cell viscoelastic deformation may favor the formation of more integrin-LN-521 bonds, increasing the adhesion between LN-521-coated probes and living cells as the 

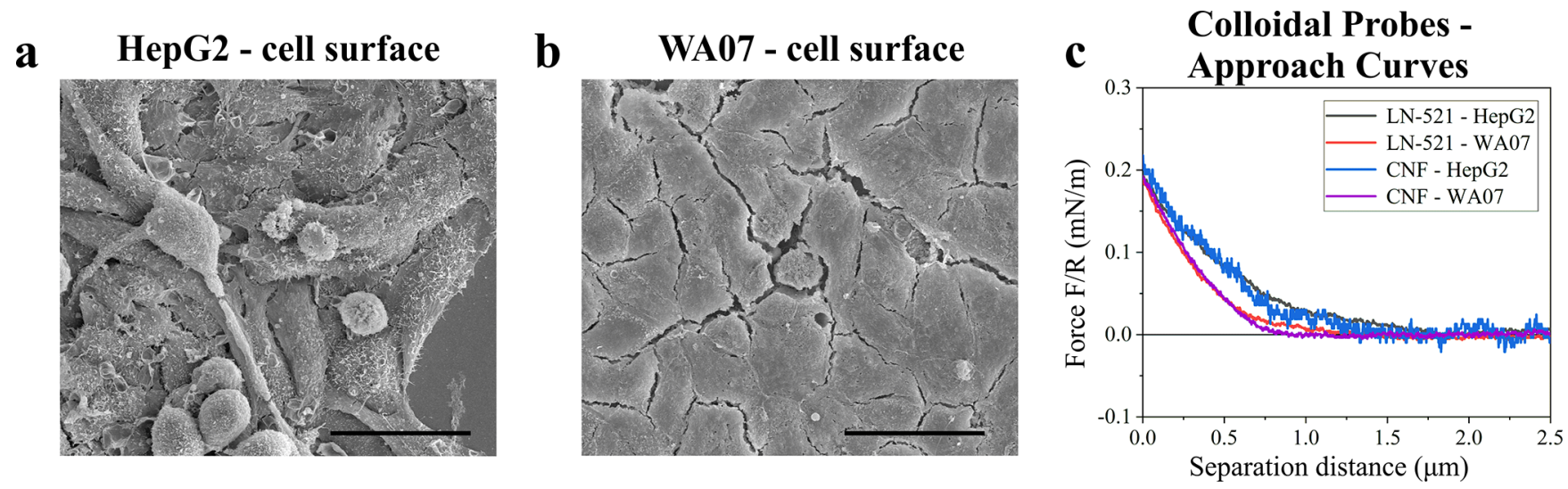

Figure 4. Effect of HepG2 and WA07 cell surface morphology on cell-biomaterial interactions. SEM images showing the cell surface morphology of HepG2 (a) and WA07 (b) cells (scale bar $40 \mu \mathrm{m}$ ). (c) Representative force curves obtained when approaching LN-521- and CNF-coated, micrometer-sized colloidal probes to living HepG2 and WA07 cells (force values normalized by the probe radius $R$ ). Force experiments were carried out in PBS+.

contact time increased. It is interesting to notice that the adhesion energy between LN-521-coated probes and dead HepG2 cells was very similar to the adhesion energy between CNF-coated probes and HepG2 cells, indicating that the lack of activation of the integrin molecules in dead cells makes the interaction between LN-521 and HepG2 cells mainly nonspecific.

The sawtooth pattern characteristic of integrin-laminin binding observed in Figure $1 \mathrm{~b}$ was expected to also be seen in Figure $2 \mathrm{~h}, \mathrm{i}$ (unlike dead cells, living cells have the capacity to activate integrins). Although some signs of that pattern could be seen in Figure $2 \mathrm{~h}$, they are not clearly distinguishable in Figure $2 \mathrm{i}$. The reason for this is that in those experiments, due to the strong adhesion between cells and laminin, stiffer cantilevers were used to be able to detach the colloidal probes from the cells within the $Z$ range of the AFM scanner (about $15 \mu \mathrm{m}$ ). The drawback of using stiffer cantilevers is the loss in force sensitivity, which made it very difficult to resolve small jumps due to single integrin-laminin unbiding events, smoothing out the retraction force curves.

The zero-force baselines are in general smoother and flatter for dead cells. The stiffer nature of dead, fixed cells limits their elongation when pulling them during the retraction of the colloidal probes, reaching a clear cell-probe detachment within the $Z$-range of the AFM scanner. In contrast, the softer living cells are more easily elongated during the retraction force measurements. In some cases (due to strong adhesion to $\mathrm{LN}$ 521 after 30 s contact time), the cell elongation approaches the $Z$-range limit of the AFM scanner, resulting in relatively short zero-force baselines in the force curves. The retraction force curves may include some viscoelastic rearrangements of the living cells during pulling, but that contributes to the total energy needed to detach the cells from the biomaterials and, consequently, should be taken into account when calculating the adhesion energy (the area enclosed by the retraction force curve - force values below 0 - and the zero-force baseline). On the other hand, the maximum detachment forces reflect the strength and amount of biomaterial-cell bonds, independently of the cell viscoelasticity. Both adhesion energies and maximum detachment forces are provided to give a more complete picture of the observed adhesion (Figures 2j,k and Tables S3 and S4).
Effect of $\mathrm{Ca}^{2+}$ and $\mathrm{Mg}^{2+}$ Cations on Cell-Biomaterial Interactions. $\mathrm{Ca}^{2+}$ and $\mathrm{Mg}^{2+}$ cations are very important for cell adhesion. Thus, they are always included in the formulation of media used for in vitro cell cultures. Divalent cations are known to play a role in integrin activation, and consequently they can be used to study the specificity of integrin-mediated cell-biomaterial interactions. ${ }^{5,15-17,54}$ It has been noted that while $\mathrm{Mg}^{2+}$ promotes integrin activation $\mathrm{Ca}^{2+}$ can either favor or hinder the activation of integrin depending on $\mathrm{Ca}^{2+}$ concentration.

In order to gain further information on how integrin activation affects cell-biomaterial interactions, we explored the effect of $\mathrm{Ca}^{2+}$ and $\mathrm{Mg}^{2+}$ ions, in combination with cell viability, on cell adhesion to LN-521 and CNF (Figures 3 and S4). PBS + (with $0.49 \mathrm{mM} \mathrm{Mg}^{2+}$ and $0.9 \mathrm{mM} \mathrm{Ca}^{2+}$ ) and PBS- (without $\mathrm{Mg}^{2+}$ and $\mathrm{Ca}^{2+}$ ) buffers were used in the experiments. PBS+ buffer was chosen because the ion concentrations were similar to commonly used cell culture media, and the concentration affects integrin activation. Unfortunately, WA07 cells were very sensitive, and they detached from the coverslips and died within $10 \mathrm{~min}$ in the absence of $\mathrm{Ca}^{2+}$ and $\mathrm{Mg}^{2+}$, preventing the force measurements using living WA07 in PBS-. This limitation was not observed with HepG2 cells.

The presence of $\mathrm{Mg}^{2+}$ and $\mathrm{Ca}^{2+}$ ions in the media did not affect the adhesion between CNF-coated colloidal probes and living HepG2 cells (Figures $3 \mathrm{a}, \mathrm{f}, \mathrm{g}$ ). A very low adhesion was observed independently of the buffer used. Low adhesion was also observed between bare glass colloidal probes and living HepG2 cells in PBS+ in control experiments reported previously by us. ${ }^{24}$ These results further support the conclusion that the interaction between CNF and HepG2 cells is not mediated by integrins. On the contrary, the presence of $\mathrm{Mg}^{2+}$ and $\mathrm{Ca}^{2+}$ ions provoked a stronger adhesion between LN-521-coated colloidal probes and living HepG2 cells (Figures 3c,f,g), suggesting that the adhesion of LN-521 to HepG2 cells is dominated by bonds with activated integrins. Nevertheless, it must be noted that removing divalent cations from the media (that is, preventing integrin activation) did not completely suppress the adhesion of LN-521 to HepG2 cells (Figures $3 c, f, g$ ), indicating that $\mathrm{LN}-521$ binding to other receptors or some nonspecific interactions with cell membranes also take place. 
Taubenberger et al. observed that the adhesion between integrin-expressing Chinese hamster ovary cells and collagen I was clearly boosted by $\mathrm{Mg}^{2+}$ cations. ${ }^{21}$ On the other hand, Trache et al. concluded that the $\mathrm{Mg}^{2+}$-promoted binding of $\alpha_{5} \beta_{1}$ integrin to fibronectin became weaker in the presence of $\mathrm{Ca}^{2+}$, suggesting the competition between $\mathrm{Mg}^{2+}$ and $\mathrm{Ca}^{2+}$ ions. ${ }^{54}$ Nevertheless, the concentrations of $\mathrm{Mg}^{2+}$ and $\mathrm{Ca}^{2+}$ ions in their work ( $4 \mathrm{mM}$ and $0.25 \mathrm{mM}$, respectively) were different from the concentrations normally used in cell culture media (for instance, different DMEM media have $0.4-0.8 \mathrm{mM}$ $\mathrm{Mg}^{2+}$ and $1.05-1.8 \mathrm{mM} \mathrm{Ca}{ }^{2+}$ ). Our results suggest that the combination of $\mathrm{Mg}^{2+}$ and $\mathrm{Ca}^{2+}$ in concentrations similar to those used in cell culture media activates integrins in HepG2 cells in contrast to previous findings, ${ }^{54}$ emphasizing that the effect of electrolytes on cell interactions is likely concentration sensitive.

Interestingly, a slightly stronger adhesion between dead cells and LN-521 and CNF was observed in the absence of $\mathrm{Mg}^{2+}$ and $\mathrm{Ca}^{2+}$ (Figures $3 \mathrm{~b}, \mathrm{~d}-\mathrm{g}$ ). Since no activation of integrins occurs in dead cells, the interactions between dead cells and biomaterials should not be affected by divalent cations. Nevertheless, nonspecific interactions not mediated by integrins could be affected by divalent cations. These interactions include van der Waals forces, hydrogen bonds, and electrostatic interactions between charged groups. Repulsive hydration forces due to the adsorption of divalent cations on hydrophilic surfaces have been previously reported, ${ }^{55}$ preventing the surfaces to approach to very short separations where the attractive van der Waals forces would be stronger. Electrostatic attractions between oppositely charged groups on cell and biomaterial surfaces could also be hindered by the adsorption of divalent cations. Altogether, the divalent cations seemed to decrease the nonspecific, attractive forces and, consequently, the adhesion of dead cells to LN-521 and CNF.

Cell Surface Morphology and Cell-Biomaterial Interactions. The cell lines chosen in this study, WA07 and HepG2, have very different surface morphology as shown in Figure 4a,b. HepG2 has relatively large microvilli at the surface and a tendency to grow on top of each other (Figure 4a), while WA07 cells have a very flat and smooth cell surface (Figure 4b). Cell-biomaterial interactions can be dictated by the different expression of cell membrane receptors, but they may also be affected by the cell surface morphology. In our experiments, the different surface morphology of HepG2 and WA07 cells can give rise to different probe-cell contact areas and, consequently, to a different number of integrin-ligand contacts. In principle, the cell surface morphology should have a stronger impact on the force curves obtained when approaching large colloidal probes to the cells. In fact, the repulsion due to the cell compression when approaching LN521 and CNF colloidal probes started at about $0.5 \mu \mathrm{m}$ longer separations for HepG2 than for WA07, well in agreement with the presence of a microvilli layer on the HepG2 cell membrane (Figure $4 \mathrm{c}$; note that the separation distances are measured with respect to the position of cell deformation at $0.2 \mathrm{mN} / \mathrm{m}$ ). The cell surface morphology may also affect the forces upon probe retraction. The different profiles of the retraction force curves, with more bumps in the case of HepG2 (Figure $2 \mathrm{~h}$ vs i; see also our previous publication ${ }^{24}$ ), could be partly due to a larger cell-probe contact area and the exposure to a higher number of integrin receptors in the case of the rougher surface of HepG2 cells. Related to this, it is known that integrins are present in the microvilli of white blood cells, ${ }^{56}$ and if integrins are also present in the microvilli of HepG2 cells, a fact that has not been confirmed yet, then the cell surface morphology would play an important role in the cell-biomaterial interactions. Nevertheless, other factors like differences in the cell response to elongation (viscoelastic deformation, cytoskeleton rearrangement) and in the density of cell membrane receptors also contribute to the shape of the retraction force curves, making it difficult to determine unambiguously the effect of the cell surface morphology. In principle, the force measurements using $65 \mathrm{~nm}$-contact radius probes should be less affected by the cell surface morphology because of the smaller tip-cell contact area. Nevertheless, the different profiles of the force curves obtained when retracting LN521-coated tips from HepG2 (Figure S5) and WA07 cells (Figure 1) could be due in part to the different surface morphology of those cells.

In summary, the results in this work demonstrated that AFM force spectroscopy techniques can be used to study the interactions of delicate stem cells that cannot be probed by SCFS. Using small well-defined probes, we were able to show how integrin location on WA07 cell colonies affected laminin adhesion, not assessable with other force-measuring techniques. An alternative way to discriminate between integrinmediated and not integrin-mediated interactions by probing the effect of cell viability and divalent cations was moreover presented. This approach is especially useful —and more suitable than the use of blocking antibodies- for cells expressing different integrin types for the same ligand. Cells genetically modified to induce or prevent the expression of some integrin types in a controlled manner would be extremely valuable systems to definitely elucidate the contribution of specific integrin-biomaterial bonds. ${ }^{21}$ Unfortunately, such genetic modification of the cells used in this work is far from reality at the moment.

\section{CONCLUSIONS}

Understanding the cell-biomaterial interaction mechanisms and the factors affecting both integrin activation and the specificity of integrin-ligand interactions can help to comprehend cell behavior in vivo and in vitro. By using AFM force spectroscopy, we quantitatively assessed the role of the intracellular integrin activation in cell-material interactions in as natural a cell environment as possible. By probing cell colonies with biomaterial-coated, well-defined probes, we showed that divalent cations, cell viability, and integrin location had a significant effect on the specific, integrinmediated interactions between human recombinant LN-521 and either human pluripotent stem cells (WA07) or human hepatocarcinoma cells (HepG2). In contrast, we observed only weak, cell receptor-independent, nonspecific interactions between wood-based CNF and cells. The developed methods enabled the study of delicate stem cells that cannot be probed by SCFS and introduced a novel approach to assess integrinmediated forces. These results increase our understanding of cell interactions and are vital for the design of cell models for different tissue engineering applications, including drug testing and regenerative medicine.

\section{ASSOCIATED CONTENT}

Supporting Information

The Supporting Information is available free of charge at https://pubs.acs.org/doi/10.1021/acsabm.9b01073. 
Illustrative explanation of the concepts of adhesion energy and maximum detachment force, representative retraction and approach force curves for different systems not included in the main text, FESEM images of a CNF-coated colloidal probe, summary tables including details of the analysis of the retraction force curves, and table showing the radii of the colloidal probes (PDF)

\section{AUTHOR INFORMATION}

\section{Corresponding Authors}

Juan José Valle-Delgado - Department of Bioproducts and Biosystems, School of Chemical Engineering, Aalto University, FI-00076 Aalto, Finland; 이이.org/0000-0002-48081730; Email: juanjose.valledelgado@aalto.fi

Monika Österberg - Department of Bioproducts and Biosystems, School of Chemical Engineering, Aalto University, FI-00076 Aalto, Finland; 이이.org/0000-0002-35589172; Email: monika.osterberg@aalto.fi

\section{Authors}

Riina Harjumäki - Department of Bioproducts and Biosystems, School of Chemical Engineering, Aalto University, FI-00076 Aalto, Finland; Division of Pharmaceutical Biosciences, Faculty of Pharmacy, University of Helsinki, FI-00014 Helsinki, Finland

Xue Zhang - Department of Bioproducts and Biosystems, School of Chemical Engineering, Aalto University, FI-00076 Aalto, Finland

Robertus Wahyu N. Nugroho - Department of Bioproducts and Biosystems, School of Chemical Engineering, Aalto University, FI-00076 Aalto, Finland

Muhammad Farooq - Department of Bioproducts and Biosystems, School of Chemical Engineering, Aalto University, FI-00076 Aalto, Finland

Yan-Ru Lou - Division of Pharmaceutical Biosciences, Faculty of Pharmacy, University of Helsinki, FI-00014 Helsinki, Finland

Marjo Yliperttula - Division of Pharmaceutical Biosciences, Faculty of Pharmacy, University of Helsinki, FI-00014 Helsinki, Finland; Department of Pharmaceutical and Pharmacological Sciences, University of Padova, I-35131 Padova, Italy

Complete contact information is available at:

https://pubs.acs.org/10.1021/acsabm.9b01073

\section{Author Contributions}

R.H., M.Ö., and J.J.V.D. planned and designed the experiments. M.Ö. obtained funding for the research. R.H. carried out the cell culturing work under the supervision of Y.R.L. and M.Y. R.H., R.W.N.N., X.Z., and J.J.V.D. carried out the AFM force measurements, and R.H., X.Z., and J.J.V.D. analyzed the data under the supervision of M.Ö. FESEM images and analysis were performed by F.M. R.H., J.J.V.D., and M.Ö. wrote the manuscript. All authors reviewed the manuscript.

\section{Notes}

The authors declare no competing financial interest.

\section{ACKNOWLEDGMENTS}

This work was funded by the Academy of Finland (project number 278279, MIMEGEL). The authors thank Prof. C. Jeffrey Brinker and his laboratory at the University of New Mexico for the SEM images of cells and Liisa Kanninen for preparing the cell cultures and the silica bioreplicas together with Yan-Ru Lou for these SEM analyses. The authors also thank Mauri Kostiainen and his group for the use of cell culture facilities at Aalto University and Mariia Bogacheva for helping with hPSC culturing. This work made use of Aalto University Bioeconomy Facilities. We acknowledge the provision of facilities and technical support by Aalto University at OtaNano - Nanomicroscopy Center (Aalto-NMC).

\section{ABBREVIATIONS}

3D, three-dimensional; AFM, atomic force microscope; CNF, cellulose nanofibrils; CPM, colloidal probe microscopy; ECM, extracellular matrix; HCC, human hepatocarcinoma cell; hPSCs, human pluripotent stem cells; LN-521, laminin-521; max, maximum; PFA, paraformaldehyde; RT, room temperature; SCFS, single-cell force spectroscopy.

\section{REFERENCES}

(1) Hynes, R. O. Integrins: a family of cell surface receptors. Cell 1987, 48, 549-554.

(2) Hynes, R. O. Integrins: versatility, modulation, and signaling in cell adhesion. Cell 1992, 69, 11-25.

(3) Humphries, M. J. The molecular basis and specificity of integrinligand interactions. J. Cell. Sci. 1990, 97, 585-592.

(4) van der Flier, A.; Sonnenberg, A. Function and interactions of integrins. Cell Tissue Res. 2001, 305, 285-298.

(5) Humphries, M. J.; McEwan, P. A.; Barton, S. J.; Buckley, P. A.; Bella, J.; Mould, A. P. Integrin structure: heady advances in ligand binding, but activation still makes the knees wobble. Trends Biochem. Sci. 2003, 28, 313-320.

(6) Luo, B. H.; Carman, C. V.; Springer, T. A. Structural basis of integrin regulation and signaling. Annu. Rev. Immunol. 2007, 25, 619647.

(7) Humphries, J. D.; Byron, A.; Humphries, M. J. Integrin ligands at a glance. J. Cell Sci. 2006, 119, 3901-3903.

(8) Moreno-Layseca, P.; Icha, J.; Hamidi, H.; Ivaska, J. Integrin trafficking in cells and tissues. Nat. Cell Biol. 2019, 21, 122-132.

(9) Huttenlocher, A.; Horwitz, A. R. Integrins in cell migration. Cold Spring Harbor Perspect. Biol. 2011, 3, a005074.

(10) Geiger, B.; Yamada, K. M. Molecular architecture and function of matrix adhesions. Cold Spring Harbor Perspect. Biol. 2011, 3, a005033.

(11) Woodside, D. G.; Liu, S.; Ginsberg, M. H. Integrin activation. Thromb. Haemostasis 2001, 86, 316-323.

(12) Hynes, R. O. Integrins: bidirectional, allosteric signaling machines. Cell 2002, 110, 673-687.

(13) Hu, P.; Luo, B. H. Integrin bi-directional signaling across the plasma membrane. J. Cell. Physiol. 2013, 228, 306-312.

(14) Dickeson, S. K.; Walsh, J. J.; Santoro, S. A. Contributions of the I and EF hand domains to the divalent cation-dependent collagen binding activity of the $\alpha_{2} \beta_{1}$ integrin. J. Biol. Chem. 1997, 272, 76617668.

(15) D'Souza, S. E.; Haas, T. A.; Piotrowicz, R. S.; Byers-Ward, V.; McGrath, D. E.; Soule, H. R.; Cierniewski, C.; Plow, E. F.; Smith, J. $\mathrm{W}$. Ligand and cation binding are dual functions of a discrete segment of the integrin $\beta_{3}$ subunit: cation displacement is involved in ligand binding. Cell 1994, 79, 659-667.

(16) Plow, E. F.; Haas, T. A.; Zhang, L.; Loftus, J.; Smith, J. W. Ligand binding to integrins. J. Biol. Chem. 2000, 275, 21785-21788.

(17) Zhang, W. M.; Käpylä, J.; Puranen, J. S.; Knight, C. G.; Tiger, C. F.; Pentikäinen, O. T.; Johnson, M. S.; Farndale, R. W.; Heino, J.; Gullberg, D. $\alpha_{11} \beta_{1}$ integrin recognizes the GFOGER sequence in interstitial collagens. J. Biol. Chem. 2003, 278, 7270-7277.

(18) Giancotti, F. G.; Ruoslahti, E. Integrin signaling. Science 1999, $285,1028-1032$.

(19) Müller, D. J.; Helenius, J.; Alsteens, D.; Dufrêne, Y. F. Force probing surfaces of living cells to molecular resolution. Nat. Chem. Biol. 2009, 5, 383-390. 
(20) Taubenberger, A. V.; Hutmacher, D. W.; Müller, D. J. Singlecell force spectroscopy, an emerging tool to quantify cell adhesion to biomaterials. Tissue Eng., Part B 2014, 20, 40-55.

(21) Taubenberger, A.; Cisneros, D. A.; Friedrichs, J.; Puech, P. H.; Müller, D. J.; Franz, C. M. Revealing early steps of $\alpha_{2} \beta_{1}$ integrinmediated adhesion to collagen type I by using single-cell force spectroscopy. Mol. Biol. Cell 2007, 18, 1634-1644.

(22) Müller, D. J.; Krieg, M.; Alsteens, D.; Dufrêne, Y. F. New frontiers in atomic force microscopy: analyzing interactions from single-molecules to cells. Curr. Opin. Biotechnol. 2009, 20, 4-13.

(23) Dufrêne, Y. F. Towards nanomicrobiology using atomic force microscopy. Nat. Rev. Microbiol. 2008, 6, 674-680.

(24) Harjumäki, R.; Nugroho, R. W. N.; Zhang, X.; Lou, Y. R.; Yliperttula, M.; Valle-Delgado, J. J.; Österberg, M. Quantified forces between HepG2 hepatocarcinoma and WA07 pluripotent stem cells with natural biomaterials correlate with in vitro cell behavior. Sci. Rep. 2019, 9, 7354.

(25) Sun, Z.; Martinez-Lemus, L. A.; Hill, M. A.; Meininger, G. A. Extracellular matrix-specific focal adhesions in vascular smooth muscle produce mechanically active adhesion sites. Am. J. Physiol. Cell. Physiol. 2008, 295, C268-C278.

(26) Lehenkari, P. P.; Horton, M. A. Single integrin molecule adhesion forces in intact cells measured by atomic force microscopy. Biochem. Biophys. Res. Commun. 1999, 259, 645-650.

(27) Patterson, K. C.; Yang, R.; Zeng, B.; Song, B.; Wang, S.; Xi, N.; Basson, M. D. Measurement of cationic and intracellular modulation of integrin binding affinity by AFM-based nanorobot. Biophys. J. 2013, 105, 40-47.

(28) Rico, P.; González-García, C.; Petrie, T. A.; García, A. J.; Salmerón-Sánchez, M. Molecular assembly and biological activity of a recombinant fragment of fibronectin $\left(\mathrm{FNIII}_{7-10}\right)$ on poly(ethyl acrylate). Colloids Surf., B 2010, 78, 310-316.

(29) Sun, Z.; Martinez-Lemus, L. A.; Trache, A.; Trzeciakowski, J. P.; Davis, G. E.; Pohl, U.; Meininger, G. A. Mechanical properties of the interaction between fibronectin and $\alpha_{5} \beta_{1}$-integrin on vascular smooth muscle cells studied using atomic force microscopy. Am. J. Physiol. Heart Circ. Physiol. 2005, 289, H2526-H2535.

(30) Weisel, J. W.; Shuman, H.; Litvinov, R. I. Protein-protein unbinding induced by force: single-molecule studies. Curr. Opin. Struct. Biol. 2003, 13, 227-235.

(31) Närvä, E.; Stubb, A.; Guzmán, C.; Blomqvist, M.; Balboa, D.; Lerche, M.; Saari, M.; Otonkoski, T.; Ivaska, J. A. A Strong Contractile Actin Fence and Large Adhesions Direct Human Pluripotent Colony Morphology and Adhesion. Stem Cell Rep. 2017, 9, 67-76.

(32) Rodin, S.; Antonsson, L.; Niaudet, C.; Simonson, O. E.; Salmela, E.; Hansson, E. M.; Domogatskaya, A.; Xiao, Z.; Damdimopoulou, P.; Sheikhi, M.; Inzunza, J.; Nilsson, A. S.; Baker, D.; Kuiper, R.; Sun, Y.; Blennow, E.; Nordenskjöld, M.; Grinnemo, K. H.; Kere, J.; Betsholtz, C.; Hovatta, O.; Tryggvason, K. Clonal culturing of human embryonic stem cells on laminin-521/E-cadherin matrix in defined and xeno-free environment. Nat. Commun. 2014, 5, 3195.

(33) Kanninen, L. K.; Harjumäki, R.; Peltoniemi, P.; Bogacheva, M. S.; Salmi, T.; Porola, P.; Niklander, J.; Smutny, T.; Urtti, A.; Yliperttula, M. L.; Lou, Y. R. Laminin-511 and laminin-521-based matrices for efficient hepatic specification of human pluripotent stem cells. Biomaterials 2016, 103, 86-100.

(34) Bhattacharya, M.; Malinen, M. M.; Lauren, P.; Lou, Y. R.; Kuisma, S. W.; Kanninen, L.; Lille, M.; Corlu, A.; GuGuen-Guillouzo, C.; Ikkala, O.; Laukkanen, A.; Urtti, A.; Yliperttula, M. Nanofibrillar cellulose hydrogel promotes three-dimensional liver cell culture. J. Controlled Release 2012, 164, 291-298.

(35) Lou, Y. R.; Kanninen, L.; Kuisma, T.; Niklander, J.; Noon, L. A.; Burks, D.; Urtti, A.; Yliperttula, M. The use of nanofibrillar cellulose hydrogel as a flexible three-dimensional model to culture human pluripotent stem cells. Stem Cells Dev. 2014, 23, 380-392.

(36) Malinen, M. M.; Kanninen, L. K.; Corlu, A.; Isoniemi, H. M.; Lou, Y. R.; Yliperttula, M. L.; Urtti, A. O. Differentiation of liver progenitor cell line to functional organotypic cultures in 3D nanofibrillar cellulose and hyaluronan-gelatin hydrogels. Biomaterials 2014, 35, 5110-5121.

(37) Dao, L.; Gonnermann, C.; Franz, C. M. Investigating differential cell-matrix adhesion by directly comparative single-cell force spectroscopy. J. Mol. Recognit. 2013, 26, 578-589.

(38) Wang, C.; Xie, X. D.; Huang, X.; Liang, Z. H.; Zhou, C. R. A quantitative study of MC3T3-E1 cell adhesion, morphology and biomechanics on chitosan-collagen blend films at single cell level. Colloids Surf., B 2015, 132, 1-9.

(39) Ducker, W. A.; Senden, T. J.; Pashley, R. M. Direct measurement of colloidal forces using an atomic force microscope. Nature 1991, 353, 239-241.

(40) Hyonchol, K.; Arakawa, H.; Osada, T.; Ikai, A. Quantification of fibronectin and cell surface interactions by AFM. Colloids Surf., B 2002, 25, 33-43.

(41) Kim, H.; Arakawa, H.; Osada, T.; Ikai, A. Quantification of cell adhesion interactions by AFM: effects of LPS/PMA on the adhesion of $\mathrm{C}_{6}$ glioma cell to collagen type I. Appl. Surf. Sci. 2002, 188, 493498.

(42) Chiéze, L.; Le Cigne, A.; Meunier, M.; Berquand, A.; Dedieu, S.; Devy, J.; Molinari, M. Quantitative characterization of single-cell adhesion properties by atomic force microscopy using proteinfunctionalized microbeads. J. Mol. Recognit. 2019, 32, No. e2767.

(43) Nugroho, R. W. N.; Harjumäki, R.; Zhang, X.; Lou, Y. R.; Yliperttula, M.; Valle-Delgado, J. J.; Österberg, M. Quantifying the interactions between biomimetic biomaterials - collagen I, collagen IV, laminin 521 and cellulose nanofibrils - by colloidal probe microscopy. Colloids Surf., B 2019, 173, 571-580.

(44) Valle-Delgado, J. J.; Johansson, L. S.; Österberg, M. Bioinspired lubricating films of cellulose nanofibrils and hyaluronic acid. Colloids Surf., B 2016, 138, 86-93.

(45) Sader, J. E.; Chon, J. W. M.; Mulvaney, P. Calibration of rectangular atomic force microscope cantilevers. Rev. Sci. Instrum. 1999, 70, 3967-3969.

(46) Hutter, J. L.; Bechhoefer, J. Calibration of atomic-force microscope tips. Rev. Sci. Instrum. 1993, 64, 1868-1873.

(47) Ralston, J.; Larson, I.; Rutland, M. W.; Feiler, A. A.; Kleijn, M. Atomic force microscopy and direct surface force measurements (IUPAC Technical Report). Pure Appl. Chem. 2005, 77, 2149-2170.

(48) Israelachvili, J. N. Intermolecular and surface forces, 3rd ed.; Elsevier: Amsterdam, 2011.

(49) Lou, Y. R.; Kanninen, L.; Kaehr, B.; Townson, J. L.; Niklander, J.; Harjumäki, R.; Brinker, C. J.; Yliperttula, M. Silica bioreplication preserves three-dimensional spheroid structures of human pluripotent stem cells and HepG2 cells. Sci. Rep. 2015, 5, 13635.

(50) Kaehr, B.; Townson, J. L.; Kalinich, R. M.; Awad, Y. H.; Swartzentruber, B. S.; Dunphy, D. R.; Brinker, C. J. Cellular complexity captured in durable silica biocomposites. Proc. Natl. Acad. Sci. U. S. A. 2012, 109, 17336-17341.

(51) Friedrichs, J.; Legate, K. R.; Schubert, R.; Bharadwaj, M.; Werner, C.; Müller, D. J.; Benoit, M. A practical guide to quantify cell adhesion using single-cell force spectroscopy. Methods 2013, 60, 169178.

(52) Schoenenberger, C. A.; Zuk, A.; Zinkl, G. M.; Kendall, D.; Matlin, K. S. Integrin expression and localization in normal MDCK cells and transformed MDCK cells lacking apical polarity. J. Cell. Sci. 1994, 107, 527-541.

(53) Jerome, W. G.; Handt, S. Endothelium and matrix interactions. In Modern visualisation of the endothelium; Polak, J. M., Ed.; CRC Press: Amsterdam, 1998; pp 93-112.

(54) Trache, A.; Trzeciakowski, J. P.; Meininger, G. A. $\mathrm{Mg}^{2+}$ modulates integrin-extracellular matrix interaction in vascular smooth muscle cells studied by atomic force microscopy. J. Mol. Recognit. 2010, 23, 316-321.

(55) Pashley, R. M.; Israelachvili, J. N. Dlvo and hydration forces between mica surfaces in $\mathrm{Mg}^{2+}, \mathrm{Ca}^{2+}, \mathrm{Sr}^{2+}$, and $\mathrm{Ba}^{2+}$ chloride solutions. J. Colloid Interface Sci. 1984, 97, 446-455. 
(56) Abitorabi, M. A.; Pachynski, R. K.; Ferrando, R. E.; Tidswell, M.; Erle, D. J. Presentation of integrins on leukocyte microvilli: a role for the extracellular domain in determining membrane localization. $J$. Cell Biol. 1997, 139, 563-571. 